\title{
A survey of Alenatea Song et Zhu, 1999 (Aranei: Araneidae)
}

\section{Обзор пауков рода Alenatea Song et Zhu, 1999 (Aranei: Araneidae)}

\author{
Yuri M. Marusik ${ }^{1-3}$, Mikhail M. Omelko ${ }^{4-5}$, \\ Pavel S. Simonov ${ }^{6}$ Xiaoqi $\mathrm{Mi}^{7}$ \\ Ю.М. Марусик ${ }^{1-3}$, М.М. Омелько ${ }^{4-5}$, П.С. Симонов ${ }^{6}$, С. Ми
}

\begin{abstract}
${ }^{1}$ Institute for Biological Problems of the North, FEB RAS, Portovaya Str. 18, Magadan, Russia. E-mail: yurmar@mail.ru
${ }^{2}$ Department of Zoology \& Entomology, University of the Free State, Bloemfontein 9300, South Africa.

${ }^{3}$ Zoological Museum, Biodiversity Unit, University of Turku, FI-20014, Finland.

${ }^{4}$ Federal Scientific Center of East Asia Terrestrial Biodiversity, FEB RAS, Vladivostok 690022, Russia. E-mail: omelkom@gmail.com

${ }^{5}$ Far Eastern Federal University, Laboratory of ecology and evolutionary biology of aquatic organisms (LEEBAO), School of Natural Sciences, Vladivostok 690091, Russia.

${ }^{6}$ Pacific Geographical Institute, FEB RAS, Radio Str. 7, Vladivostok, 690041, Russia E-mail: palzpss@yandex.ru

${ }^{7}$ College of Agriculture and Forestry Engineering and Planning, Guizhou Provincial Key Laboratory of Biodiversity Conservation and Utilization in the Fanjing Mountain Region, Tongren University, Tongren 554300, Guizhou, China. E-mail: mixiaoqi1018@163.com

${ }^{1}$ Институт биологических проблем Севера, ДВО РАН, Портовая 18, Магадан 685000 Россия.

${ }^{4}$ Федеральный научный центр Биоразнообразия наземной биоты Восточной Азии ДВО РАН, Владивосток 690022, Россия.

5 Дальневосточный федеральный университет, Лаборатория экологии и эволюционной биологии водных организмов (ЛЭБВО), Школа естественных наук, Владивосток 690091, Россия.

${ }^{6}$ Тихоокеанский институт географии ДВО РАН, ул. Радио 7, Владивосток 690041, Россия.
\end{abstract}

KEY WORDS: Araneae, Far East Asia, Primorskii Krai.

КЛЮЧЕВЫЕ СЛОВА: Araneae, Дальневосточная Азия, Приморский край, Приморье.

ABSTRACT. Alenatea Song et Zhu, 1999, a genus currently known from three species distributed in the southeastern Palaearctic, is briefly surveyed, and the relationships of the genus are discussed. The previously unknown male of $A$. wangi Zhu et Song, 1999 is described, and both sexes of $A$. fuscocolorata (Bösenberg et Strand, 1906) (the generotype) and the female of $A$. wangi are redescribed in detail. The possible synonymy of $A$. touxie Zong et Zhu, 1999 with $A$. wangi is discussed, and a new combination is proposed as $A$. acusiseta (Zhu et Song, 1994) comb.n. (ex. Araneus).

How to cite this article: Marusik Yu.M., Omelko M.M., Simonov P.S., Mi X. 2020. A survey of Alenatea Song et Zhu, 1999 (Aranei: Araneidae) // Arthropoda Selecta. Vol.29. No.4. P.487-494. doi: 10.15298/ arthsel. 29.4.12

РЕЗЮМЕ. Кратко рассмотрен род Alenatea Song et Zhu, 1999, известый по трём видам из юго-восточной Палеарктики. Описан ранее неизвестный самец вида $A$. wangi Zhu et Song, 1999. Подробно переописаны типовой вид рода $A$. fuscocolorata (Bösenberg et Strand, 1906) и самка A. wangi. Возможно, что A. touxie Zong et Zhu, 1999, вид, описанный по иллюстрациям, может быть синонимом $A$. wangi. Обнаружено, что Araneus acusisetus Zhu et Song, 1994 также принадлежит к роду Alenatea, предложена новая комбинация Alenatea acusiseta
(Zhu et Song, 1994) comb.n. Кратко обсуждены взаимоотношения в роде Alenatea.

\section{Introduction}

The current paper is the third in our series on Araneidae of the Far East [Marusik et al., 2015, 2020], and concerns Alenatea Song et Zhu, 1999, a small genus with three named species distributed in the southeastern Palaearctic [WSC, 2020]. Two species of Alenatea, A. wangi Zhu et Song, 1999 and A. touxie Song et Zhu, 1999, are restricted to China and known from females only [WSC, 2020]. While studying spiders from the Russian Far East, we recognized several females whose epigynes are similar to those of $A$. wangi. Recently, we obtained a sample containing such females collected together with males. The goals of this paper are to provide a description of the unknown male of $A$. wangi, a detailed redescription of both sexes of the generotype and the female of $A$. wangi, establish a new combination and discuss the limits and relationships of the genus.

\section{Material and Methods}

Specimens were photographed using a Nikon DS-Ri2 camera attached to a Nikon SMZ25 stereomicroscope at the Far Eastern Federal University (Vladivostok). Photographs 


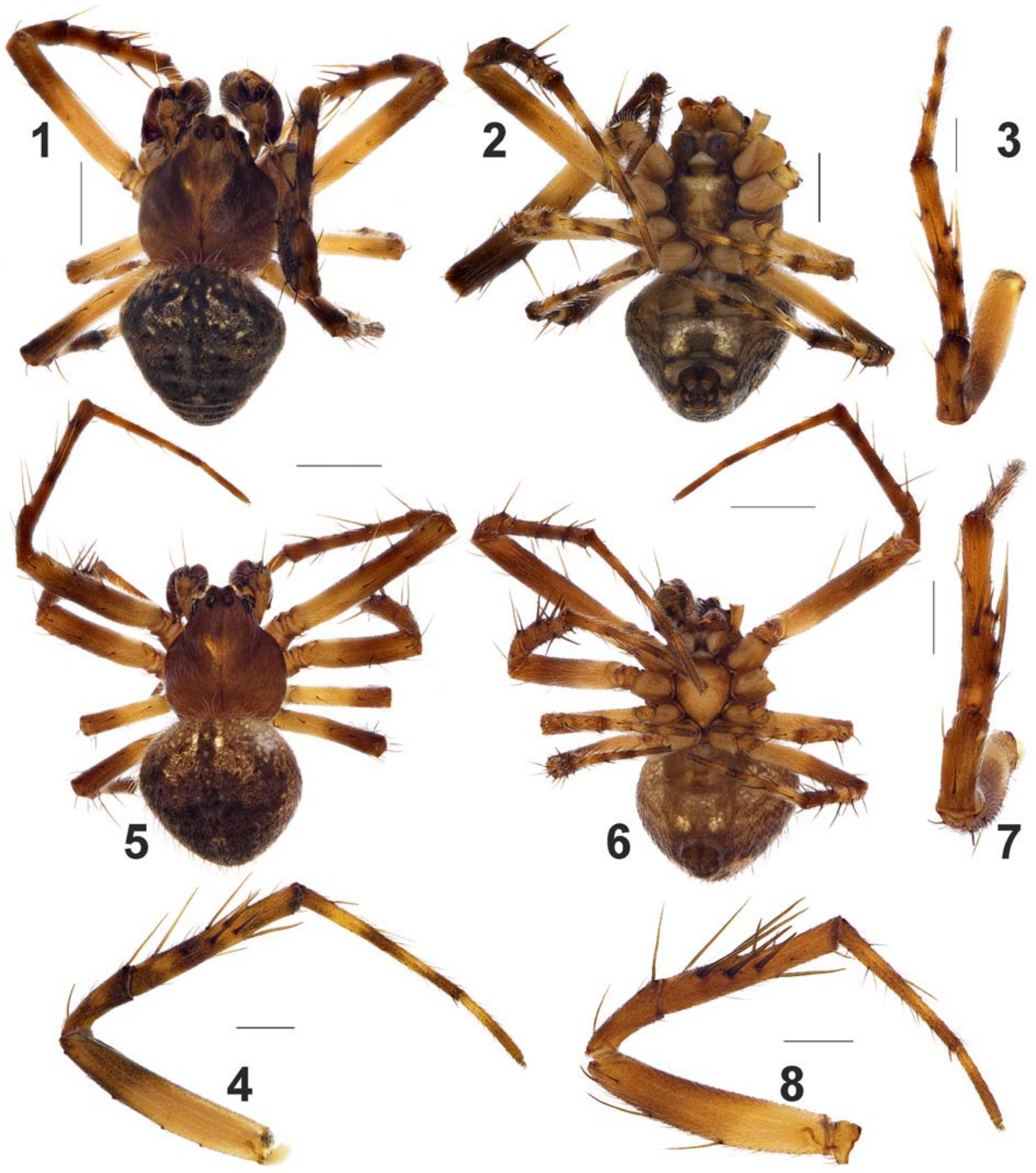

Figs 1-8. General appearance and legs II of the males of Alenatea fuscocolorata (1-4) and A. wangi (5-8). 1, 3, 5, 7 - dorsal; 2, 6 ventral; 4,8 - prolateral. Scale $=1 \mathrm{~mm}$ for general appearance and $0.5 \mathrm{~mm}$ for legs.

Рис. 1-8. Внешний вид и нога II самца Alenatea fuscocolorata (1-4) и A. wangi (5-8). 1, 3, 5, 7 — дорзально; 2, 6 — вентрально; 4, 8 - пролатерально. Масштаб 1 мм для внешнего вида и 0,5 мм для ног.

were taken in dishes filled with alcohol, with soft white paper at the bottom. Digital images were montaged by using Zerene Stacker software (http://zerenesystems.com/cms/stacker). All measurements are in millimeters. All examined material will be deposited in the Zoological Museum of the Moscow State University, Moscow, Russia (ZMMU), Far Eastern Federal University (FEFU), Vladivostok, Russia and Tongren University (TRU), Tongren China.
Abbreviations used in the text and figure plates: Leg segments: $\mathrm{Fe}$ - femur, $\mathrm{Pt}$ - patella, $\mathrm{Mt}$ - metatarsus, $\mathrm{Ti}$ tibia, Ta - tarsus. Copulatory organs: Bt - base of terminal apophysis, $\mathrm{Co}$ - conductor, $\mathrm{Cg}$ - copulatory opening, Em - embolus, $M a$ - median apophysis, $M m$ - major tooth of the median apophysis, $S a$ - subterminal apophysis, $S s$ - sickle shaped tip of $T r, T p$ - prolateral arm of terminal apophysis, $\operatorname{Tr}$ - retrolateral arm of terminal apophysis. 


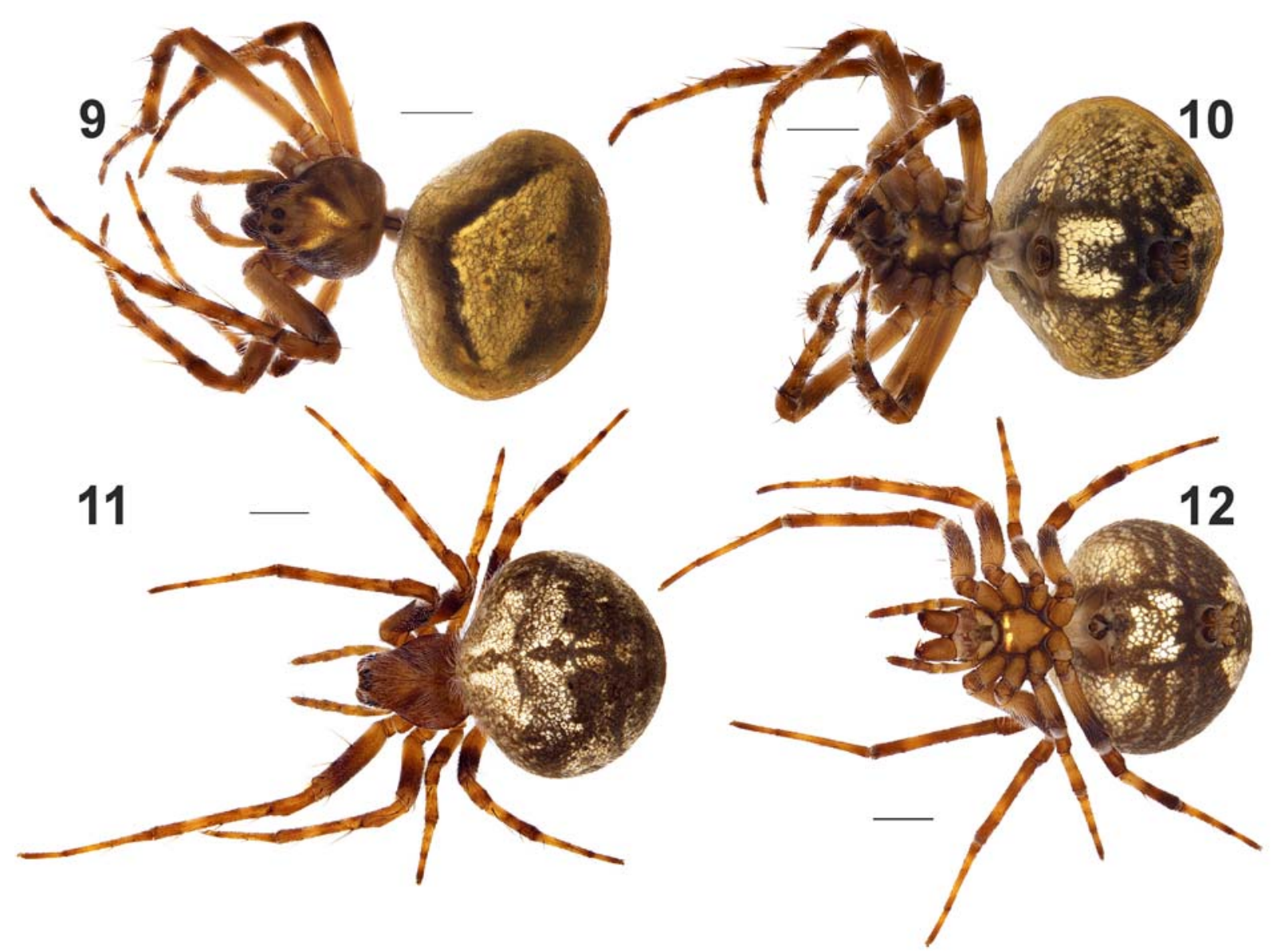

Figs 9-12. General appearance of females of Alenatea fuscocolorata (9-10) and A. wangi (11-12). 9, 11 - dorsal; 10, 12 - ventral. Scale $=1 \mathrm{~mm}$ 1 мм.

Рис. 9-12. Внешний вид Alenatea fuscocolorata (9-10) и A. wangi (11-12). 9, 11 - дорзально; 10, 12 - вентрально. Масштаб

\section{Taxonomic survey}

\section{Alenatea Song et Zhu, 1999}

Alenatea Song et Zhu in Song et al., 1999: 230.

TYPE SPECIES: Aranea fuscocolorata Bösenberg et Strand, 1906 from Japan.

COMMENTS. The genus was briefly described in the illustrated catalogue of Chinese spiders and compared to Agalenatea Archer, 1951, which was assumed to be a close relative in the informal diagnosis [Song et al., 1999]. This assumption is merely based on the similarities of the abdomen shape, which is wider than long. The copulatory organs of the two genera are considerably different, and they apparently belong to different suprageneric taxa. According to Scharff et al. [2020] and Kallal et al. [2020], Agalenatea is grouped in the same clade as Neoscona Simon, 1864. Both genera Neoscona and Agalenatea have similar copulatory organs (e.g. epigyne with inflexible scape and male palp with median apophysis having a claw-like process, a short embolus and a long terminal apophysis subdivided into two arms). Alenatea (was never subject of the phylogenetic study) appears more similar to Araneus Clerck, 1757 s.l. by having a flexible scape, a large median apophysis with 2 claws and a long embolus and terminal apophysis. However, Alenatea males can be distinguished from Araneus by the long, almost filamentous embolus, and the terminal apophysis deeply divided into two branches, rather than having short emboli bearing caps and an undivided terminal apophysis as in Araneus.

DIAGNOSIS. The shape of the abdomen in females is similar to some small Araneus species by being wider than long. Alenatea species can be distinguished from somatically similar, small-sized Araneus spp. by the straight, short and not sigmoid scape (vs. scape longer than wide, with several turns). Males can be recognized by the long, filamentous embolus lacking a cap (vs. a short, non-filamentous embolus with a cap), straight median apophysis with 1-2 teeth on the distal side ( $v s$. median apophysis with processes on both sides), terminal apophysis with a large base $(B t)$ and 2 arms: prolateral $(T p)$ and retrolateral $(T r)$ (vs. terminal apophysis with a small base and only one arm), long (as long as the tegulum), roundly bent embolus ( $v s$. short embolus, no longer than the median apophysis).

COMPOSITION. We consider four species in this genus: A. fuscocolorata, A. acusiseta (Zhu et Song, 1994) comb.n., A. touxie Song et Zhu, 1999 and $A$. wangi Zhu et Song, 1999.

DISTRIBUTION. Restricted to the southeastern Palaearctic (Eastern China, Korea, Japan and the southern part of easternmost Russia). 

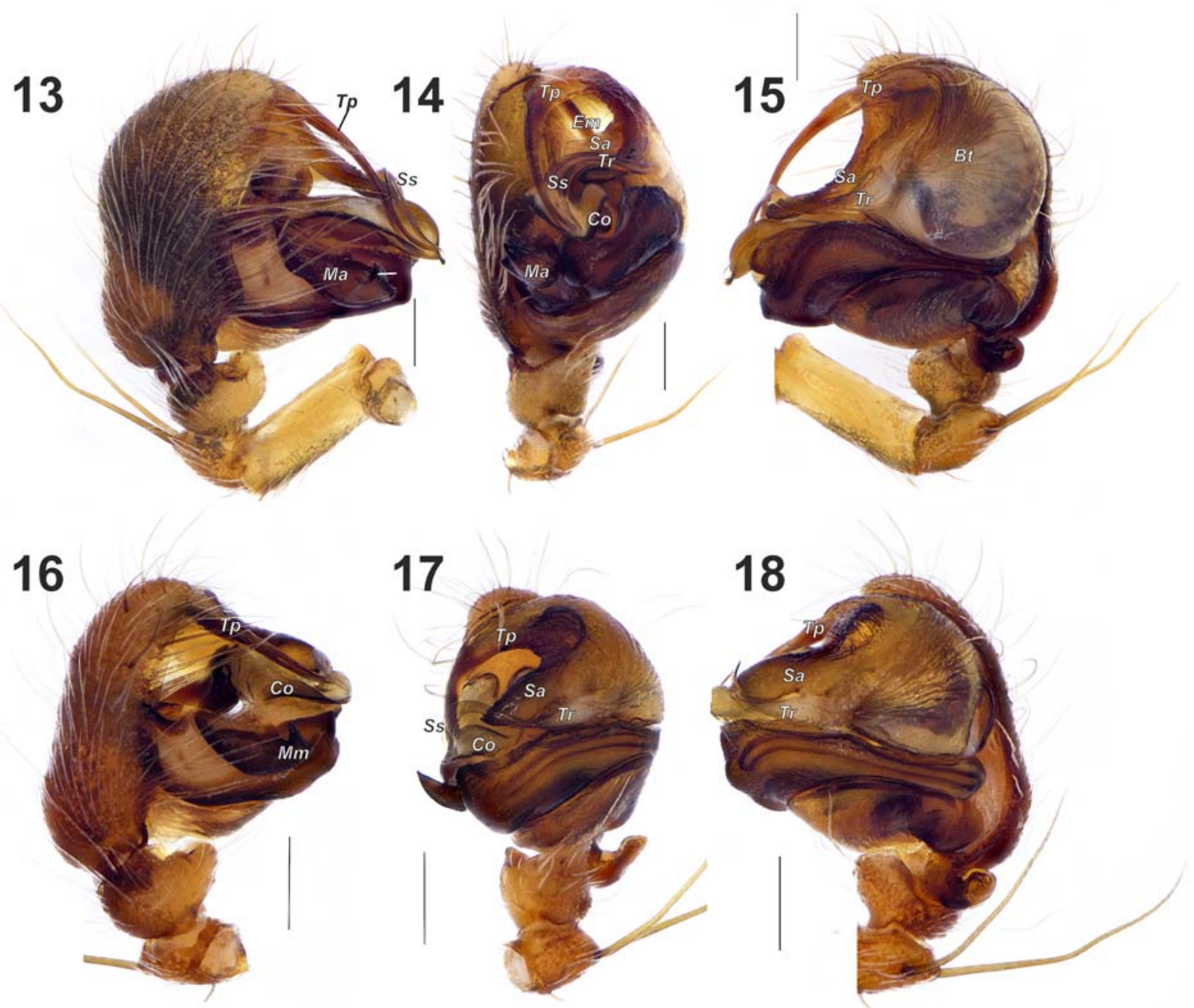

Figs 13-18. Male palp of Alenatea fuscocolorata (13-15) and A. wangi (16-18). 13, 16 - prolateral; 14, 17 - ventral; 15,18 retrolateral. Scale $=0.2 \mathrm{~mm}$. Abbreviations: $\mathrm{Bt}$ - base of terminal apophysis, $\mathrm{Co}$ - conductor, Em — embolus, $\mathrm{Ma}$ - median apophysis, $\mathrm{Mm}$ - major tooth of the median apophysis, Sa - subterminal apophysis, Ss - sickle-shaped tip of $\mathrm{Tr}$, $\mathrm{Tp}$ - prolateral arm of terminal apophysis, $\operatorname{Tr}$ - retrolateral arm of terminal apophysis.

Рис. 13-18. Пальпа Alenatea fuscocolorata (13-15) и A. wangi (16-18). 13, 16 - пролатерально; 14, 17 - вентрально; 15, 18 ретролатерально. Масштаб 0,2 мм. Сокращения: $\mathrm{Bt}$ - основание терминального отростка, Со — кондуктор, Еm — эмболюс, Ма медиальный отросток, $\mathrm{Mm}$ - крупный зуб медиального отростка, $\mathrm{Sa}$ - субтерминальный отросток, $\mathrm{Ss}$ - серповидный конец $\mathrm{Tr}$, $\mathrm{Tp}$ - пролатеральный вырост терминального отростка, $\operatorname{Tr}$ - ретролатеральный вырост терминального отростка.

Alenatea fuscocolorata (Bösenberg et Strand, 1906)

Figs 1-4, 9-10, 13-15, 19-21, 25-26, 29. $\left.\left(\mathrm{O}^{\top}+\right)^{\prime}\right)$

Alenatea fuscocolorata: Song et al., 2001: 183, f. 107A-G $\left.\left(\mathrm{O}^{\top}+\right)^{\prime}\right)$

Alenatea fuscocolorata: Tanikawa, 2007: 77, f. 213, 637-638

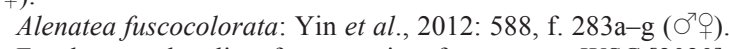
For the complete list of taxonomic references see WSC [2020]. MATERIAL EXAMINED: RUSSIA, Primorskiy Prov.: $10^{7}$ 3 우 (FEFU), Russky Isl., 42 ${ }^{\circ} 59^{\prime} \mathrm{E} 131^{\circ} 55^{\prime} \mathrm{N}$, meadow, 5.07.2006 (P.S. Simonov); 1 \& (ZMMU), Khasanskiy Dist., Kedrovaya Pad' Reserve, $43^{\circ} 6^{\prime} \mathrm{N} 131^{\circ} 30^{\prime} \mathrm{E}, 1990$, (A.V. Tanasevitch); 2 우

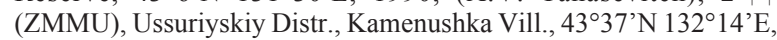
1984-1985 (A.V. Antropov); 1 (IBPN), Khankaiskiy Distr., Turiy

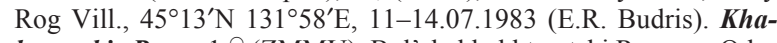
barovskiy Prov.: 1 \& (ZMMU), Bol'shekhekhtsyrtski Reserve, Odyr River, $48^{\circ} 16^{\prime} \mathrm{N} 134^{\circ} 49^{\prime} \mathrm{E}, 19.08 .1992$ (D.K. Kurenshchikov); $3 \mathrm{O}^{7} \mathrm{O}^{7}$ (ZMMU), Sea of Okhotsk, Malyshevskaya Protoka \{specific local- ity not found, possibly mislabeled\}, 10.06.1911 (V.K. Soldatov). Amur Area: 1 \& 3 juv. (ZMMU), Khingan Distr., Lebedinskoye Forestry, Sopka Boguchanka, 7.08.1983 (Yu.M. Marusik). Sakhalin Isl.: 1 juv. (IBPN), Uskovo River (tributary of Tym' River), ca $12 \mathrm{~km}$ NNE of Tymovskoye Town, $50^{\circ} 56.098^{\prime} \mathrm{N} 142^{\circ} 45.541^{\prime} \mathrm{E}$, 6.08.2001 (Yu.M. Marusik). CHINA, Guizhou Prov.: 2 O$^{7} 0^{7} 3$ 우 (TRU), Tongren City, Bijiang District, Chuandong Township, Kongshengyuan, $109.132^{\circ} \mathrm{E} 27.472^{\circ} \mathrm{N}$, ca. $572 \mathrm{~m}, 13.05 .2018$ (X.Q. Mi et al.); $1 O^{T}$ (TRU), Qiandongnan Miao and Dong Autonomous Prefecture, Shibing County, Chengguan Township, $108.82^{\circ} \mathrm{E} 27$. $32^{\circ} \mathrm{N}$, ca. 705 m, 21.07.2019 (X.Q. Mi et al.); Liaoning Prov.: $2 O^{7} O^{7} 8$ 우 (TRU), Shenyang City, Huanggu District, Beiling Park, $41.502^{\circ} \mathrm{N} 123.252^{\circ} \mathrm{E}$, ca. $69 \mathrm{~m}, 14.07 .2019$ (X.Q. Mi, C. Wang).

DIAGNOSIS. The male of this species differs from the sibling A. wangi by the prolateral arm of the terminal apophysis $(T p)$ : apophysis in mesal view longer than bulb vs. shorter (cf. Figs 13 and 16); prolateral arm of the terminal apophysis sigmoid $v s$. roundly bent (cf. Figs 13, 14 and 16, 

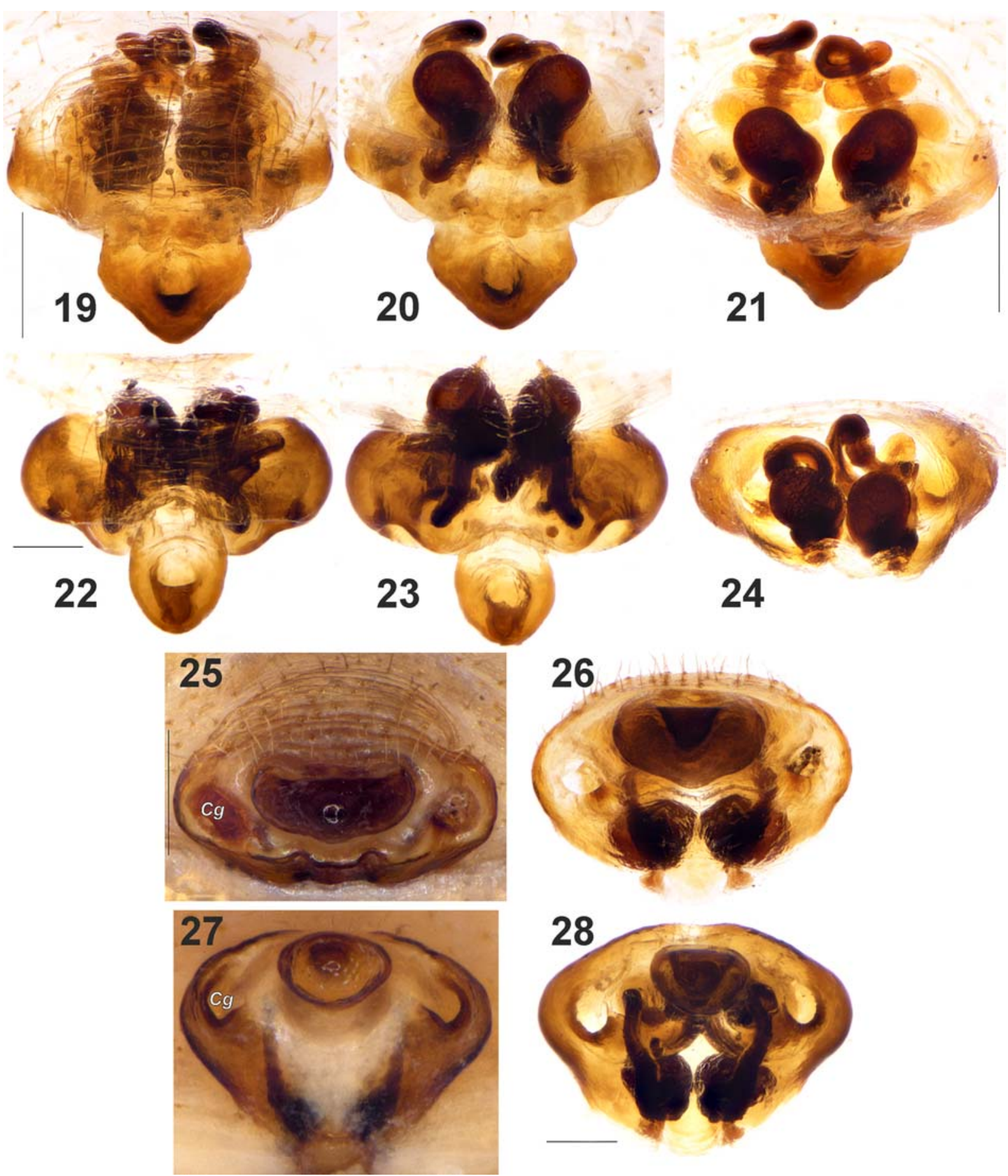

Figs 19-28. Epigynes of Alenatea fuscocolorata (19-21, 25-26) and A. wangi (22-24, 27-28). 19, 22 - anterior; 20, 23 - posterior; 21, 24 - dorsal; 25, 27 - ventral, intact; 26, 28 - ventral, macerated. Scale $=0.2 \mathrm{~mm}$. Abbreviation: $C g$ - copulatory opening.

Рис. 19-28. Эпигина Alenatea fuscocolorata (19-21, 25-26) и A. wangi (22-24, 27-28). 19, 22 - спереди; 20, 23 - сзади; 21, 24 дорзально; 25, 27 - вентрально, интактная; 26, 28 - вентрально, мацерированнная. Масштаб 0,2 мм. Сокращение: $\mathrm{Cg}-$ копулятивное отверстие.

17); relatively longer median apophysis $(M a), 3$ times longer than wide vs. 2.5; more inclined major tooth $(\mathrm{Mm})$ of the median apophysis (cf. Figs 13 and 16). The female of $A$. fuscocolorata differs from congeners by the pentagonal scape being wider than long vs. scape rounded, and longer than wide.
DESCRIPTION. Male. Total length 3.83. Carapace 2.02 long, 1.71 wide. Carapace dark brown with light brown pars cephalica. Chelicerae gray with yellow mesal side. Maxillae dark brown, labium brown with yellowish anterior edge. Sternum black with yellow asterisk-like mark (Fig. 2). Femora yellow, dark gray distally. Other leg segments brown 


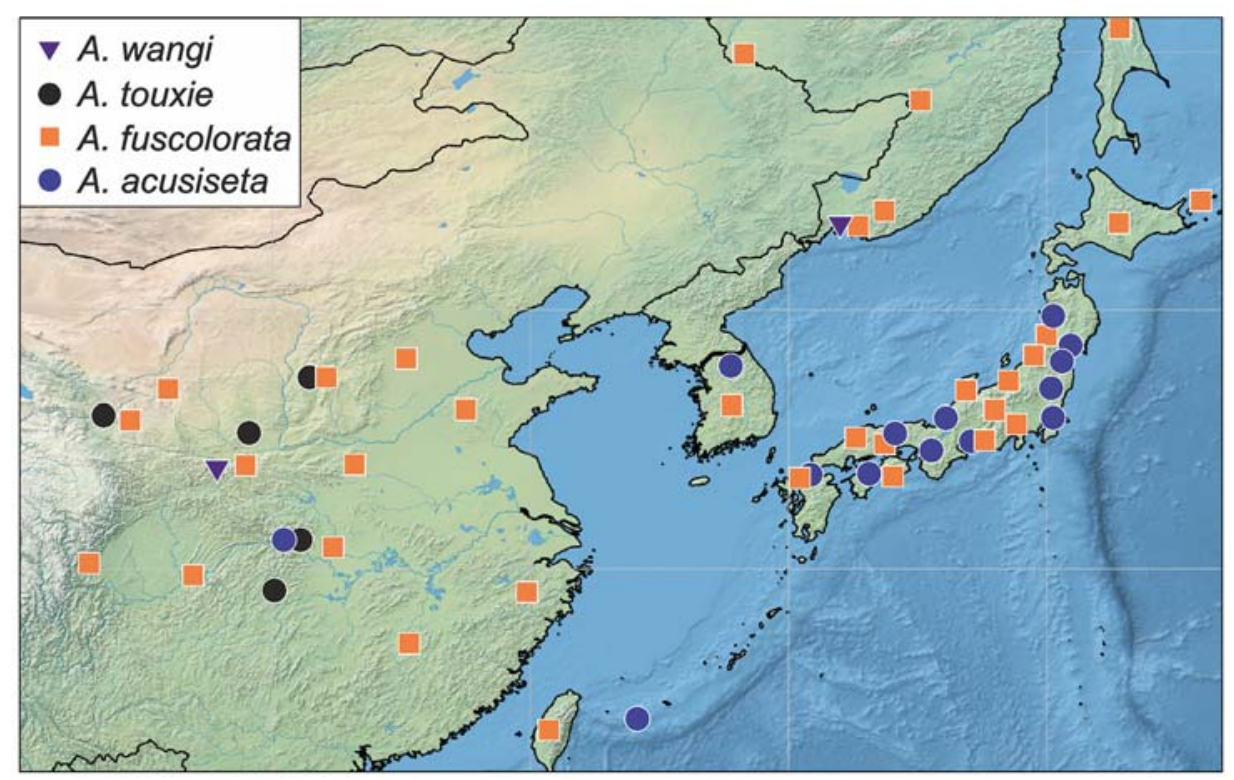

Fig. 29. Distribution records of Alenatea acusiseta, A. fuscocolorata, A. touxie and A. wangi.

Рис. 29. Известные точки находок Alenatea fuscocolorata, A. touxie и A. wangi.

with yellow spots and rings. Tibia II with 4 large prolateral spines (Figs 3-4).

Abdomen dorsally almost black with complex pattern (Fig. 1) consisting of white spots and yellowish areas. Sides of abdomen blackish with yellow spots. Abdomen ventrally dark gray with white guanine П-mark (Fig. 2).

Palp as in Figs 13-15. Femur short, almost 2 times shorter than cymbium, 2.7 times longer than wide; patella and tibia subequal in length; cymbium unmodified; tegulum long, sperm duct roundly bent in terminal $1 / 3$; median apophysis $(M a)$ long, ca 2.9 times longer than wide, with 2 teeth terminally; terminal apophysis with large base $(B t)$ and 2 arms: prolateral $(T p)$ and retrolateral $(T r)$, prolateral arm obscures long, belt-like embolus $(E m)$, prolateral arm long, gently sigmoid, longer than bulb in prolateral view; retrolateral arm $(T r)$ sigmoid, long, with sickle-shaped tip $(S s)$ together with prolateral arm and embolus on elongate conductor $(\mathrm{Co})$; subterminal apophysis $(\mathrm{Sa})$ elongate, about as long as median apophysis.

\begin{tabular}{lllllll}
\multicolumn{7}{c}{ Leg lengths } \\
& $\mathrm{Fe}$ & $\mathrm{Pa}$ & $\mathrm{Ti}$ & $\mathrm{Mt}$ & $\mathrm{Ta}$ & Total \\
I & 2.72 & 1.00 & 2.58 & 2.25 & 0.91 & 9.46 \\
II & 2.08 & 0.87 & 1.69 & 1.70 & 0.77 & 7.11 \\
III & 1.38 & 0.49 & 0.66 & 0.81 & 0.52 & 3.86 \\
IV & 1.96 & 0.65 & 1.10 & 1.34 & 0.63 & 5.68
\end{tabular}

Female. Total length 5.00-5.07. Carapace 2.02-2.16 long, $1.72-1.87$ wide. Carapace brown with light V-mark (Fig. 9) on pars cephalica (weakly visible in one of the specimens). Chelicerae brown or dark brown with yellow mesal sides. Coloration of mouthparts as in male. Sternum black with yellow asterisk-like mark, size of which differs in different specimens (Fig. 10). Coloration of the legs as in male, slightly lighter.

Abdomen dorsally brown with numerous guanine spots forming a complex pattern (Fig. 9) which differs among all studied specimens. Sides of abdomen gray with guanine spots. Ventrally as in male, П-mark more pronounced (Fig. 10).

\begin{tabular}{ccccccc}
\multicolumn{6}{c}{ Leg lengths (specimen with carapace 2.03 long) } \\
& $\mathrm{Fe}$ & $\mathrm{Pa}$ & $\mathrm{Ti}$ & $\mathrm{Mt}$ & $\mathrm{Ta}$ & Total \\
& 2.31 & 0.89 & 1.91 & 1.60 & 0.77 & 7.48 \\
$\mathrm{II}$ & 1.76 & 0.86 & 1.54 & 1.25 & 0.68 & 6.09 \\
$\mathrm{II}$ & 1.28 & 0.46 & 0.64 & 0.73 & 0.51 & 3.62 \\
$\mathrm{~V}$ & 1.82 & 0.64 & 1.05 & 1.09 & 0.56 & 5.16
\end{tabular}

Epigyne as in Figs 19-21, 25-26. Plate 1.7 times wider than long; scape pentagonal in anterior view, wider than long, suboval in ventral view, almost 3 times wider than long; copulatory openings $(\mathrm{Cg})$ separated by 4 diameters; copulatory duct forming 3 loops; receptacles oval, close together.

DISTRIBUTION. This species is restricted to Far East Asia, known from the Amur River middle flow (Blagoveshchensk) to Kunashir Island and Japan, and south to Taiwan [WSC, 2020: Li, Lin, 2016] (Map 1).

Alenatea wangi Zhu et Song, 1999

Figs 5-8, 11-12, 16-18, 22-24, 27-28, 29.

Alenatea wangi Zhu et Song, in Song et al., 1999: 235, f. $133 \mathrm{~L}-\mathrm{N}(+)$.

Alenatea touxie: Song et al., 2001: 185, f. 108A-C ( + , reproduced figs of $A$. wangi from Song et al., 1999).

COMMENTS. Reproduced figures of the original description of $A$. wangi were used to illustrate $A$. touxie in Song et al. [2001]. We failed to locate the type specimens as they were not found at Hebei University where M.S. Zhu and D.S. Song used to work.

MATERIAL EXAMINED: RUSSIA, Primorskiy Kray: 3 우 (FEFU), Askold Isl., 42 $45^{\prime} \mathrm{E} 132^{\circ} 20^{\prime} \mathrm{N}$, meadow, 1.08 .2016 (P.S. Simonov); $10^{\top} 3$ 우 (FEFU), Shkotovskiy Dist., env. of Anisimovka Vill., $43^{\circ} 09^{\prime} \mathrm{N} 132^{\circ} 48^{\prime} \mathrm{E}$, meadow, 18.06 .2015 (P.S. Simonov); $10^{7} 1$ क (ZMMU), same data; 3 우 (ZMMU), Lazo Distr., Lazo, $43^{\circ} 23^{\prime} \mathrm{N} 133^{\circ} 54^{\prime} \mathrm{E}, 6-10.07 .2006$ (V. Shokhrin, Y. Sundukov).

DIAGNOSIS. For the male, see the diagnosis of $A$. fuscocolorata. The female of $A$. wangi is similar to that of $A$. touxie but differs by having a shorter scape (length/width ratio 1.3 vs. 1.7). 
DESCRIPTION. Male. Total length 3.25-3.33. Carapace 1.69-1.70 long, 1.41-1.43 wide.

Carapace dark brown with yellowish spot on pars cephalica (clearly visible in one specimen (Fig. 5) and barely visible in others). Pars cephalica covered with long, white setae. Chelicerae light brown with yellow mesal sides. Maxillae brown, labium brown with yellowish anterior edge. Sternum yellow with indistinct gray spots at edges (Fig. 6) Femora brown distally and yellow proximally; patellae brown; other leg segments brown with yellow rings. Tibia II with 4 large prolateral and dorsal spines (Figs 7-8).

Abdomen almost black dorsally, with a complex pattern (Fig. 5) consisting of white spots and dark stripes. Dorsal pattern differs among the studied males. Sides of abdomen gray with yellowish spots. Ventrally dark grey, with a few white guanine spots (Fig. 6).

Palp as in Figs 16-18; sperm duct straight, bent in terminal $1 / 10$ of its length; median apophysis $(M a)$ about 2.5 times longer than wide; subterminal apophysis $(S a)$ large, not hidden, with sharply pointed tip and large base; prolateral arm of terminal apophysis $(T p)$ straight and shorter than bulb in prolateral view, roundly bent in ventral view.

\begin{tabular}{|c|c|c|c|c|c|}
\hline \multicolumn{6}{|c|}{ Leg lengths (smallest specimen) } \\
\hline $\mathrm{Fe}$ & $\mathrm{Pa}$ & $\mathrm{Ti}$ & Mt & $\mathrm{Ta}$ & Total \\
\hline 2.42 & 0.84 & 2.17 & 1.66 & 0.77 & 7.86 \\
\hline 184 & 0.73 & 1.43 & 1.25 & 0.62 & 5.87 \\
\hline 1.1 & 0.41 & 0.57 & 0.62 & 0.46 & 3.17 \\
\hline 1.65 & 0.56 & 0.94 & 1.05 & 0.53 & 4.73 \\
\hline
\end{tabular}

Female. Total length 4.37-5.65. Carapace 1.70-2.06 long, 1.47-1.7 wide. Carapace dark yellowish brown on pars cephalica and medially in some specimens (Fig 11). Whole carapace covered with long, white setae. Chelicerae brown with slightly lighter mesal sides. Coloration of mouthparts as in males. Sternum light brown with bright yellow spots at anterior edge (Fig. 12). Number and shape of these spots differ among different specimens. Coloration of legs as in males, slightly lighter.

Abdomen dorsally gray with a complex pattern (Fig. 11) consisting of white spots and dark stripes of different shapes. Dorsal pattern differs among different specimens. Sides of abdomen brown with numerous guanine spots. Abdomen ventrally grayish with three distinct areas of guanine spots (Fig. 12).

Leg lengths (specimen with carapace 2.06 long)

$\begin{array}{lllllll} & \mathrm{Fe} & \mathrm{Pa} & \mathrm{Ti} & \mathrm{Mt} & \mathrm{Ta} & \text { Total } \\ \text { I } & 2.87 & 0.98 & 2.39 & 1.81 & 0.74 & 8.79 \\ \text { II } & 2.19 & 0.91 & 1.78 & 1.38 & 0.66 & 6.92 \\ \text { III } & 1.36 & 0.58 & 0.70 & 0.80 & 0.44 & 3.88 \\ \text { IV } & 2.15 & 0.74 & 1.34 & 1.31 & 0.57 & 6.11\end{array}$

Epigyne as in Figs 22-24, 27-28. Plate 2.5 times wider than long in anterior view; scape ca. 1.3 times longer than wide in anterior view and 1.5 times longer than wide in ventral view; copulatory openings separated by about 3 diameters; copulatory ducts forming about 2 loops; receptacles oval, touching.

DISTRIBUTION. Exact distribution is unclear because the same figures have been used to illustrate both $A$. wangi in Song et al. [1999] and A. touxie in Song et al. [2001]. This species was described from Shanxi, and the new records presented here extend the known range over $1800 \mathrm{~km}$ to the northeast (Map 1).

\section{Alenatea touxie Song et Zhu, 1999}

Agalenatea angulopicta: Yin et al., 1997: 111, f. 36a-d ( + misidentified).
Alenatea touxie Song et Zhu, in Song et al., 1999: 235 (+, described based on figs and description of A. angulopicta from Yin et al., 1997).

Alenatea touxie: Song et al., 2001: 185, f. 108A-C (, figures are reproduced from those used in the description of $A$. wangi).

Alenatea touxie: Yin et al., 2012: 590, f. 284a-d ( + , reproduced figures of A. angulopicta from Yin et al., 1997).

COMMENTS. This species lacks type material, and the description was based on the redescription of a misidentified Agalenatea angulopicta (Schenkel, 1953), currently a junior synonym of $A$. fuscocolorata.

According to Li \& Lin [2016], this species has been reported from Hebei, Shanxi, Hubei, Hunan and Gansu Provinces of China, but some, if not all, of the records may refer to $A$. wangi. It is possible that these two nominal species are synonyms.

\section{Alenatea acusiseta (Zhu et Song, 1994) comb.n.} $\mathrm{C}\left(\mathrm{O}^{7}\right)$.

Araneus acusisetus Zhu et Song, in Zhu et al., 1994: 27, f. 2AAran

raneus acusisetus: Tanikawa, 2001: 83, f. 73-74, 77-78 (

Araneus fuscocoloratoides Namkung, 2002: 254, 620, f. $19.16 \mathrm{a}-\mathrm{b}\left(\mathrm{O}^{\mathrm{T}}+\right)$.

Araneus acusisetus: Tanikawa, 2007: 82, f. 238-239, 679-680 $\left.\left(\mathrm{O}^{7}+\right)^{\prime}\right)$

For complete list of references see WSC [2020].

MATERIAL EXAMINED: CHINA, Guizhou Prov: $20^{7} \sigma^{7}$ 18 우 (TRU), Songtao County, Wuluo Township, Taohuayuan Village, $108.472^{\circ} \mathrm{E} 27.582^{\circ} \mathrm{N}$, ca. $787 \mathrm{~m}, 29.05 .2017$ (X.Q. Mi); $1 \mathrm{O}^{7}$ 4 +o (TRU), Leishan Co., Leigongshan National Nature Reserve, Xiangshuiyan, $108.102^{\circ} \mathrm{E} 26.222^{\circ} \mathrm{N}$, ca. $1204 \mathrm{~m}, 1.05 .2018(\mathrm{H}$. Liu, G.J. Tian); 2 O $^{7} 0^{\top} 5$ 웅 (TRU), Yinjiang County, Ziwei Township, Huguosi, $108.282^{\circ} \mathrm{E} 27.542^{\circ} \mathrm{N}$, ca. $1500 \mathrm{~m}, 25.04 .2020$ (X.Q. Mi, C. Wang).

COMMENTS: Because this species is well illustrated in several publications (see above), we are not providing new figures.

DIAGNOSIS. The male differs from those of A. fuscocolorata and $A$. wangi by the very broad median apophysis (length/width ratio $1.4 v s .>2$ ) widening terminally. The female differs from congeners by the shape and size of the scape: triangular tip, scape longer than epigynal plate and tip wider than half of epigynal width ( $v s$. tip not triangular and not wider than half of the plate width). The epigyne of this species has slit like almost indistinct copulatory openings $v s$. round and distinct.

DESCRIPTION. See Tanikawa [2001].

COMMENTS. The male palp, and particularly the sickle-shaped tip of the terminal apophysis $(S s)$ with a large base and the filamentous embolus, leaves no doubts that it is related to $A$. fuscocolorata, and therefore we transfer this species to Alenatea.

DISTRIBUTION. Known from China (Hubei only), South Korea and all of Japan [WSC, 2020: Tanikawa, 2007].

Acknowledgments. We thank Ilari E. Sääksjärvi (Zoological Museum, University of Turku, Finland) for permission to use the lab facilities. We thank Feng Zhang (Baodin, China) for his efforts in locating the types of $A$. wangi, Shuqiang Li (Beijing, China) for providing comments on the status and distribution of $A$. touxie, and Anna Šestáková (Trnava, Slovakia) for providing comments on the terminology of the male palp. Alexander A. Fomichev (Barnaul, Russia) and Alireza Zamani (Turku, Finland) reviewed the manuscript. English of the earlier draft was corrected by 
Alireza Zamani. Xiaoqi Mi was supported by the National Natural Sciences Foundation of China (NSFC-31660609) and the Science and Technology Project Foundation of Guizhou Province, China ([2020]1Z014).

English of the final draft was kindly checked and corrected by Sarah Crews (San Francisco, USA).

\section{Compliance with ethical standards}

Conflict of Interest: The authors declare that they have no conflict of interest.

Ethical approval: No ethical issues were raised during our research.

\section{References}

Kallal R.J., Dimitrov D., Arnedo M.A., Giribet G., Hormiga G. 2020. Monophyly, taxon sampling, and the nature of ranks in the classification of orb-weaving spiders (Araneae: Araneoidea) // Systematic Biology. Vol.69. No.2. P.401-411. doi:10.1093/ sysbio/syz043

Li S.Q., Lin Y.C. 2016. [Species catalogue of China. Animalia Vol.3. Invertebrata (I)]. The Science Publishing Company. Vol.2. No.1. P.1-549 [in Chinese].

Marusik Yu.M., Omelko M.M., Simonov P.S. 2020. A redescription of Aculepeira matsudae (Aranei: Araneidae), a species recently found in Far East Russia // Arthropoda Selecta Vol.29. No.1. P.121-126. doi:10.15298/arthsel.29.1.10

Marusik Yu.M., Omelko M.M., Simonov P.S., Koponen S. 2015. New data about orb-weaving spiders (Aranei: Araneidae and Tetragnathidae) from the Russian Far East // Arthropoda Selecta. Vol.24. No.2. P.207-214.

Namkung J. 2002. [The spiders of Korea]. Seoul: Kyo-Hak Publishing Co. 648 p. [In Korean]
Scharff N., Coddington J.A., Blackledge T.A., Agnarsson I., Framenau V.W., Szüts T., Hayashi C.Y., Dimitrov D. 2020. Phylogeny of the orb-weaving spider family Araneidae (Araneae: Araneoidea) // Cladistics. Vol.36. No.1. P.1-21.

Shinkai A., Andoh A., Tanikawa A., Ikeda H., Kuwata T. 2020. CD Japanese Spiders, ver.2020. Self-published by the authors.

Song D.X., Zhu M.S., Chen J. 1999. The spiders of China. Shijiazhuang: Hebei Science and Technology Publishing House. 640 p.

Song D.X., Zhu M.S., Chen J. 2001. [The Fauna of Hebei, China: Araneae]. Shijiazhuang: Hebei Science and Technology Publishing House. 510 p. [In Chinese]

Tanikawa A. 2001. Twelve new species and one newly recorded species of the spider genus Araneus (Araneae: Araneidae) from Japan // Acta Arachnologica. Vol.50. No.1. P.63-86.

Tanikawa A. 2007. An identification guide to the Japanese spiders of the families Araneidae, Nephilidae and Tetragnathidae. Arachnological Society of Japan. 121 p.

WSC. 2020. World Spider Catalog. Version 21.5. Natural History Museum Bern, online at http://wsc.nmbe.ch, accessed on 8th of November, 2020.

Yin C.M., Peng X.J., Yan H.M., Bao Y.H., Xu X., Tang G., Zhou Q.S., Liu P. 2012. [Fauna Hunan: Araneae in Hunan, China]. Changsha: Hunan Science and Technology Press. 1590 p. [In Chinese]

Yin C.M., Wang J.F., Zhu M.S., Xie L.P., Peng X.J., Bao Y.H. 1997. [Fauna Sinica: Arachnida: Araneae: Araneidae]. Beijing: Science Press. 460 p. [In Chinese]

Zhu M.S., Song D.X., Zhang Y.Q., Wang X.P. 1994. [On some new species and new records of spiders of the family Araneidae from China] // Journal of Hebei Normal University (Nat. Sci. Ed.). 1994 (Suppl.). P.25-52 [in Chinese].

Responsible editor K.G. Mikhailov 